Journal of Social Sciences 7 (1): 42-50, 2011

ISSN 1549-3652

(C) 2010 Science Publications

\title{
Green Chemistry: Educating Prospective Science Teachers in Education for Sustainable Development at School of Educational Studies, USM
}

\author{
${ }^{1}$ Mageswary Karpudewan, ${ }^{1}$ Zurida Hj Ismail and ${ }^{2}$ Norita Mohamed \\ School of Educational Studies, \\ School of Chemical Sciences, \\ University Sains Malaysia, 11800 USM, Penang. Malaysia
}

\begin{abstract}
Problem statement: Agenda 21 of Chapter 36 spelled out the role of education in imparting knowledge that could develop behavioral change that leads to sustainable lifestyle. In line with this, University Sains Malaysia has embarked on various projects and activities in educating and preparing the campus community towards tomorrow's sustainability. One of the strategies taken to address ESD is through the integration of green chemistry experiments into the curriculum. Approach: Green chemistry which is a laboratory-based pedagogy was employed to educate the student teachers enrolled in the chemistry teaching methods course at the (name of department). By incorporating Green Chemistry principles into the chemistry curriculum, these future educators can provide students with a positive message about what chemists are doing for the environment in fulfilling the obligation and responsibilities of environmental stewardship. Educators would also have the opportunity to transform student perceptions about the role chemistry plays in society and to address the need to discover and develop sustainable chemistry for the future. Results: Assessment of the impact of the experience on student-teachers showed them to be intrinsically motivated in committing pro-environmental actions. The environmental values and environmental attitudes of the student teachers were observed to undergo change as well. Conclusion: This study has been shown that it is possible by educational means to encourage the inculcation of positive environmental values and to teach the skills and cognitive basis required for active participation as individuals and members of the community.
\end{abstract}

Key words: Green chemistry, teacher education, Education for Sustainable Development (ESD), prospective science teachers, Environmental Education (EE)

\section{INTRODUCTION}

Sustainable development, simply put is ensuring a better quality of life for everyone, both now and for generations to come. Although the idea is simple, the task is substantial. There is a great need to educate the people with the knowledge, skills and appropriate values to ensure sustainability. Chapter 36 of Agenda 21 stresses that "education is critical for achieving environmental and ethical awareness, values and attitudes, skills and behavior consistent with sustainable development and effective public participation in decision making'. According to Fien and Tilbury (1996) education is critical to sustain the future. It is a solution for environmental ills both to provide information and to start to change our values and behaviors. As Orr (1991) proposed, all education is environmental education.
The importance of Environmental Education (EE) in Malaysia is highlighted in the National Policy on the Environment (2002). One of the key areas of the Green Strategies outlined in the policy is 'Education and Awareness'. Among the strategies for Education and Awareness include integrating environment and development into educational activities from school to tertiary institutions of which relevant method and materials will be developed and to review education curricula at all levels to ensure a multidisciplinary approach with environment and development issues. In terms of formal education, the Ministry of Education has developed a curriculum for EE and has implemented various teaching and learning strategies to enhance environmental awareness and internalize values on the importance of environmental protection. In line with the National Education Policy,

Corresponding Author: Mageswary Karpudewan, School of Educational Studies, University Sains Malaysia, 1

1800 USM, Penang. Malaysia 
'Environmental Education across the Curriculum' was introduced in both primary and secondary schools in 1990s. EE is infused in each subject in schools, rather than taught as a single subject. Consequently, our secondary school students and pre-service teachers possess high level of awareness on issues concerning the environment (Karpudewan et al., 2006; 2006). However, findings from the survey also showed that they failed to act on the emerging environmental problem. The students generally lack the willingness to change their personal life-style and to commit actions to protect the environment. Sharifah and Hashimah (2006) also reported that there is still considerable apathy among Malaysian students to engage pro-actively in environmental behaviors.

The rising interest in environmental literacy and education for sustainability has created expectations that timely, accurate content should be taught at all levels particularly teacher education curriculum. Teacher training institutions have an important role to play due to the impact that they have on the curricula and policy for the implementation of these curricula to bring about systematic, economically efficient changes. Powers (2004) also noted that pre-service teacher's curriculum possesses a multiplier effect where one teacher has the potential to impact a number of students taught throughout his/her career. Teachers as mediators should be able to influence both the teaching and learning process in schools and social processes outside the schools. However, as noted by Powers (2004); McKeown-Ice (2000); Peter et al. (2007); Markku and Riitta (2000) and May (2000), inadequate teacher training in EE and sustainable development concepts could be one of the factors that hinder the development of value based education in schools which would ultimately result in behavior change.

Yencken et al. (2000) suggested everyday experiences and knowledge as well as the three pillars of sustainable dimensions; economic, environment and society could be reflected into the curriculum by integrating sustainable development concepts (Table 1).

Table 1: Sustainable development concepts (Yencken et al., 2000)

\begin{tabular}{|c|c|}
\hline Carrying capacity & $\begin{array}{l}\text { The capacity of ecosystems to support continued growth in population numbers, resource consumption and waste } \\
\text { production. }\end{array}$ \\
\hline Steady-state economy & A non-growth economy in which the demands of resource consumption are in balance with resource supply and production. \\
\hline Ecospace & $\begin{array}{l}\text { The total amount of energy, land, water and other resources that can beused regionally or globally without environmental } \\
\text { damage, disadvantaging the capacities of others to meet their basic needs or impinging on the rights of future generations. }\end{array}$ \\
\hline Sustainable development & $\begin{array}{l}\text { A process by which the needs of present generations can be satisfied without compromising the ability of future generations } \\
\text { to satisfy their needs. }\end{array}$ \\
\hline Ecological footprint & $\begin{array}{l}\text { The area of land and water needed to support the total flow of energy and materials consumed by a community } \\
\text { or population indefinitely. }\end{array}$ \\
\hline Natural resource accounting & $\begin{array}{l}\text { A strategy that helps a household, corporation or government calculate its real wealth, i.e. the value of total } \\
\text { economic production minus the value of the natural and social capital consumed to achieve it. }\end{array}$ \\
\hline Eco-efficiency & $\begin{array}{l}\text { A strategy for maximizing the productivity of material and energy inputs to a production process whilst also } \\
\text { reducing resource consumption and waste production and generating cost savings and competitive advantage. }\end{array}$ \\
\hline Life Cycle Analysis & $\begin{array}{l}\text { A management tool for identifying the net flows of resource and energy used in the production, consumption } \\
\text { and disposal of a product or service in order to leverage eco-efficiency gains. }\end{array}$ \\
\hline Sustainable consumption & $\begin{array}{l}\text { The use of services and related products to satisfy basic human needs and bring a better quality of life while } \\
\text { minimizing the use of natural resources and toxic materials as well as emissions of waste and pollutants over the } \\
\text { life cycle of the service or product. }\end{array}$ \\
\hline The $5 \mathrm{Rs}$ & Reduce, reuse, renew, recycle and rethink! \\
\hline Local-global links & $\begin{array}{l}\text { The recognition that the consumption of a product or service in one part of the world is dependent on flows of } \\
\text { energy and materials in other parts of the world and that this creates potential opportunities and losses } \\
\text { economically, socially and environmentally at all points in the local-global chain. }\end{array}$ \\
\hline Interdependence & $\begin{array}{l}\text { The relationships of mutual dependence between all elements and } \\
\text { life forms, including humans, within natural systems. }\end{array}$ \\
\hline Biodiversity & $\begin{array}{l}\text { The diverse and interdependent composition of life forms in an ecosystem that is necessary for sustaining flows } \\
\text { of energy and materials indefinitely. }\end{array}$ \\
\hline Interspecies equity & A consideration of the need for humans to treat creatures decently and protect them from cruelty and avoidable suffering. \\
\hline Intra-generational equity & $\begin{array}{l}\text { A consideration of the need to ensure that all individuals and } \\
\text { societies have access to the resources required to satisfy basic human needs and rights }\end{array}$ \\
\hline Inter-generational equity & $\begin{array}{l}\text { A consideration of the need to live off net resource production rather than environmental capital in order to } \\
\text { enable future generations access a world that is at least as diverse and productive as the one each generation inherits. }\end{array}$ \\
\hline Human rights & $\begin{array}{l}\text { The fundamental freedoms of conscience and religion, expression, peaceful assembly and association, which } \\
\text { ensure access to democratic participation and meeting basic human needs. }\end{array}$ \\
\hline Basic human needs & $\begin{array}{l}\text { The needs and right of all people and societies for fair and equitable access to flows of energy and materials for } \\
\text { survival and a satisfying quality of life within the limits of the Earth. }\end{array}$ \\
\hline Media literacy & $\begin{array}{l}\text { An appreciation of the role of the public media and marketing and advertising industries in creating perceptions } \\
\text { of needs and wants and the skill to identify the roles thee media may play in encouraging and undermining sustainable } \\
\text { consumption. }\end{array}$ \\
\hline Democracy & The right of all people to access channels for community decision-making. \\
\hline
\end{tabular}


This integration approach was adopted in a chemistry teaching methods course offered to pre-service chemistry teachers. Apart from the traditional topics on pedagogy, environmental and sustainable development concepts were also introduced through green chemistry. Green chemistry is used to describe the design of chemical processes and products to reduce or eliminate the use and generation of hazardous substances and to conserve materials and energy. The basic concept is to solve pollution problems by eliminating or minimizing pollution in the first instance.

Green chemistry is a student centered active learning approach of teaching chemistry content in an eco-friendly way. According to Haack et al. (2005), green chemistry is a useful tool to increase awareness and teach sophisticated problem solving skills through the content of chemistry. Green chemistry or sustainable chemistry is interdisciplinary in nature and involves exploration of the environment. Hence, it can serve as a theme to facilitate integrative and interdisciplinary learning experiences where students use their critical thinking and communication skills to address complex problems facing the chemical enterprise. While green chemistry encompasses human health and the environment, it is guided by very specific principles of chemical practices as illustrated in Table 2 (Anastas and Wagner, 1998). Through application and extension of the 12 principles, green chemistry can contribute to sustainable development (Wardencki et al., 2005).
Purpose of study: The purpose of the study is to assess the effectiveness of green chemistry experiments in inculcating environmental value change, attitudinal change and enhancing intrinsic motivation among preservice teachers.

\section{MATERIALS AND METHODS}

The sample consisted of 110 pre-service teachers from a local university. At the time of the study the subjects were either in their second or third year into the Science Education Program and enrolled in a chemistry teaching methods course. Apart from the lectures, students were required to conduct green chemistry experiments each week during the tutorial sessions. In all, they had to complete 10 green experiments for the entire semester. The experiments were adapted and modified to fulfill the requirements of the existing secondary school integrated chemistry curriculum (Table 3).

A revised version of the Questionnaire on Environmental Values (Kempton et al., 1995) was used to determine the value orientation of the pre-service teachers. QEV contains 37 items. The items were classified into three categories: egocentric, homocentric and biocentric. The scale used in this questionnaire is a six point Likert-type scale: strongly agree, agree, slightly agree, disagree, slightly disagree or strongly disagree.

Table 2: Green chemistry principles (Anastas and Wagner, 1998)

\begin{tabular}{|c|c|}
\hline Prevention & It is better to prevent waste than to treat or clean up waste after it has been created. \\
\hline Atom economy & $\begin{array}{l}\text { Synthetic methods should be designed to maximize the incorporation of all materials used in } \\
\text { the process into the final product. }\end{array}$ \\
\hline Less hazardous chemical synthesis & $\begin{array}{l}\text { Wherever practicable, synthetic methods should be designed to use and generate substances } \\
\text { that possess little or no toxicity to people or the environment. }\end{array}$ \\
\hline Designing safer chemicals & $\begin{array}{l}\text { Chemical products should be designed to affect their desired function while minimizing their } \\
\text { toxicity. }\end{array}$ \\
\hline Safer solvents and auxiliaries & $\begin{array}{l}\text { The use of auxiliary substances (e.g., solvents or separation agents) should be made unnecessary } \\
\text { whenever } \\
\text { possible and innocuous when used. }\end{array}$ \\
\hline Design for energy efficiency & $\begin{array}{l}\text { Energy requirements of chemical processes should be recognized for their environmental and } \\
\text { economic impacts and should be minimized. If possible, synthetic methods should be conducted at } \\
\text { ambient temperature and pressure. }\end{array}$ \\
\hline Use of renewable feedstock & $\begin{array}{l}\text { A raw material or feedstock should be renewable rather than depleting whenever technically } \\
\text { and economically practicable. }\end{array}$ \\
\hline Reduce derivatives & $\begin{array}{l}\text { Unnecessary derivatization (use of blocking groups, protection/de-protection and temporary } \\
\text { modification of physical/chemical processes) should be minimized or avoided if possible, } \\
\text { because such steps require additional reagents and can generate waste. }\end{array}$ \\
\hline Catalysis & Catalytic reagents (as selective as possible) are superior to stoichiometric reagents. \\
\hline Design for degradation & $\begin{array}{l}\text { Chemical products should be designed so that at the end of their function they break down into } \\
\text { Innocuous degradation products and do not persist in the environment. }\end{array}$ \\
\hline Real-time analysis for pollution prevention & $\begin{array}{l}\text { Analytical methodologies need to be further developed to allow for real-time, in process } \\
\text { monitoring and control prior to the formation of hazardous substances. }\end{array}$ \\
\hline Inherently safer chemistry for accident prevention & $\begin{array}{l}\text { Substances and the form of a substance used in a chemical process should be chosen to } \\
\text { minimise the potential for chemical accidents, including releases, explosions and fires. }\end{array}$ \\
\hline
\end{tabular}


Table 3: Traditional experiment and the parallel green chemistry experiment

Traditional existing experiments
Heating and cooling curve with naph
Fractional distillation of petroleum d
Production of ethanol from glucose
Rate of reaction with sodium thiosulph
Production of carbon dioxide from hyd
Cleaning with Soap
Polymers
Brief introduction on global warming
Sources of electricity
Production of Hydrogen gas
Reaction with chlorine gas
Not available

The items in the questionnaire were scored 1-6 with 1 being most environmental and 6 the least environmental (Kempton et al., 1995). QEV is considered to have high validity and has received favorable reviews (McMillan et al., 2004). The internal consistency as measured by Cronbach's alpha is 0.834 .

Motivation Towards Environment Scale (MTES) was used to measure the motivation of the participants towards the environment (Pelletier et al., 1998). MTES is known to possess high level of validity. In terms of reliability MTES possesses high level of internal consistency and satisfactory test-retest reliability (Villacorta et al., 2003; Seguin et al., 1999). MTES contains 24 items with six subscales: intrinsic motivation, integrated regulation, identified regulation, introjected regulation, external regulation and amotivation. According to Seguin et al. (1999) these motivational types can be arranged in a continuum based on the level of self-determination. Intrinsic motivation represents the highest level of motivation with amotivation being the lowest and characterized by loss of personal control. Behavior is controlled when it is regulated either by external contingencies or introjected demands and autonomous when it is intrinsically motivated or regulated by identification. The internal consistency as measured by Cronbach's alpha is 0.756 .

The New Environmental Paradigm (NEP) scale was used to measure the change in environmental attitude of the students. The NEP scale contains 12 items with eight items worded in agreement of the acceptance of NEP, while the other four $(3,4,6,10)$ in disagreement. The pro-NEP items were assigned the following numerical scores: 4 for strongly agree, 3 for mildly agree, 2 for mildly disagree and lastly 1 for strongly disagree. The scoring system for the anti-NEP item was reversed. NEP is known to possess high level high level of internal consistency, validity and satisfactory test-retest reliability (Dunlap et al., 2008; Taskin, 2009). Cronbach's alpha is used to determine the internal consistency or average correlation of items
Green chemistry experiments

Heating and cooling with lauric acid

Production of biodiesel

Production of ethanol from molasses

Rate of reaction with vitamin C

Production of carbon dioxide from vinegar and sodium hydrogen carbonate.

Cleaning with liquid carbon dioxide

Biodegradable polymers

Visualize the impact of global warming

Electricity from waste

Production of hydrogen gas

Production of chlorine gas and the reactions

The principle of atom economy

in the survey instrument to gauge its reliability. The value of Cronbach's alpha obtained for this study is 0.702 . This value is similar to the values reported by others (Dunlop et al., 2008).

The MTES, QEV and NEP were administered twice during the semester: during the first meeting for the course and after completion of all the 10 green chemistry experiments (13th week). The experiments were conducted during the tutorial sessions. SPSS was used to analyze the collected data. A paired sample ttest was performed.

\section{RESULTS}

In this study the effectiveness of green chemistry experiments in inculcating environmental value change, attitudinal change and motivational change was measured. Value change was measured with QEV, attitudinal change with NEP and motivational change with MTES. Table 4 shows the mean values for both the pre and post test of the MTES. A paired t-test result showed that there is a significant increase in the post test mean values of intrinsic $(\alpha=0.019 ; \mathrm{p}<0.05)$, integration $(\alpha=0.018 ; \mathrm{p}<0.05)$ and identification $(\alpha=$ $0.021 ; \mathrm{p}<0.05)$. Significant decreases in post test mean value of introjected regulation $(\alpha=0.031 ; p<0.05)$ was observed. A non significant decrease were obtained for external regulation $(\alpha=0.724 ; \quad p>0.05)$ and amotivation $(\alpha=0.148 ; p>0.05)$.

The results demonstrated that green chemistry experiments have significantly enhanced students' selfdetermined motivation (intrinsic motivation, integrated regulation and identified regulated motivation). Additionally, the higher mean value obtained for intrinsic motivation indicates that the attainment of selfdetermined intrinsic motivation is higher than the integrated and identified regulation. Lower mean values for external regulated motivation and amotivation indicates that generally the students' amotivation is low. Green chemistry experiment's impact on external regulated motivation and amotivation is minimal. 
Therefore, non-significant changes were observed for the non-self determined extrinsic motivations of external regulation and amotivation. However, green chemistry has significantly influenced non-self determined introjection regulated motivation.

Each item in the QEV was scored from 1- 6, with 1 being the most environmental and 6 being the least environmental (Kempton et al., 1995). Therefore, a decrease in the mean score between the pre and posttest means shows that the students' answers have become more environmental. Table 5 shows the paired sample statistics for the QEV. The overall results indicate that when all the items were taken into consideration, the students' responses were more environmentally inclined as indicated by the significant decrease in the mean value from 3.0266 to 2.4431 with a p-value of $0.000(\mathrm{p}<0.05)$ (Table 5). They also seemed to become less egocentric as shown by a significant increase in the mean value of the pre test and post test from 3.6679-3.9307 (p-value of 0.001; $\mathrm{p}<0.05$ ). For the homocentric category the students' responses showed that they had become more homocentric as shown by the decrease in the mean values of the pre and post test. However, the difference is not significant ( $p$-value of $0.0592 ; p>0.05$ ).

Table 4: Paired sample statistics for MTES

\begin{tabular}{|c|c|c|c|c|c|}
\hline \multirow{2}{*}{$\begin{array}{l}\text { Motivation } \\
\text { scale }\end{array}$} & \multicolumn{2}{|c|}{ Mean value } & \multirow[b]{2}{*}{ SD } & \multirow[b]{2}{*}{ t-value } & \multirow[b]{2}{*}{ Significance } \\
\hline & Pre test & Post test & & & \\
\hline \multicolumn{6}{|l|}{ Intrinsic } \\
\hline motivation & 4.0110 & 4.1270 & 0.6906 & 2.375 & 0.019 \\
\hline Integration & 3.5690 & 3.7110 & 0.8291 & 2.370 & 0.018 \\
\hline Identification & 3.9180 & 4.0010 & 0.5353 & 2.323 & 0.021 \\
\hline Introjections & 3.7460 & 3.6310 & 0.7428 & 2.177 & 0.031 \\
\hline \multicolumn{6}{|l|}{ External } \\
\hline regulation & 2.8770 & 2.8560 & 0.8092 & 0.354 & 0.724 \\
\hline Amotivation & 2.3450 & 2.2250 & 1.1670 & 1.454 & 0.148 \\
\hline
\end{tabular}

Figure 1 shows the environmental values profile based on the mean scores for each category from both the pre and post tests. From the figure it can be seen that there is a difference between the pre and post test scores. The difference is statistically significant for both ego and ecocentric categories. However, the change in the homocentric category is not significant.

Table 6 presents the environmental attitude means, standard deviations and t-value for each item in NEP. Significant difference in the mean values was obtained for all the items in NEP. This indicates that green chemistry experiments have enhanced the students' environmental attitudes.

Increase in the mean values was noticed between the pre test and post test for items 1, 2, 5, 7, 8, 9, 11 and 12. These 8 items are worded in agreement with NEP.

Table 5: Paired sample statistics for QEV

\begin{tabular}{|c|c|c|c|c|c|}
\hline Category & $\begin{array}{l}\text { Pre- } \\
\text { test mean }\end{array}$ & $\begin{array}{l}\text { Standard } \\
\text { deviation }\end{array}$ & $\begin{array}{l}\text { Post- } \\
\text { test mean }\end{array}$ & $\begin{array}{l}\text { Standard } \\
\text { deviation }\end{array}$ & $\mathrm{P}$ value \\
\hline \multicolumn{6}{|l|}{$(\alpha=0.05)$} \\
\hline Egocentric & 3.6679 & 0.5380 & 3.9307 & 0.5494 & 0.001 \\
\hline Homoc & 2.8700 & 0.3699 & 2.8442 & 0.3315 & 0.0592 \\
\hline Ecocentric & 2.5419 & 0.5558 & 2.3132 & 0.5303 & 0.004 \\
\hline Overall & 3.0266 & 0.3024 & 2.4431 & 0.2970 & 0.000 \\
\hline
\end{tabular}

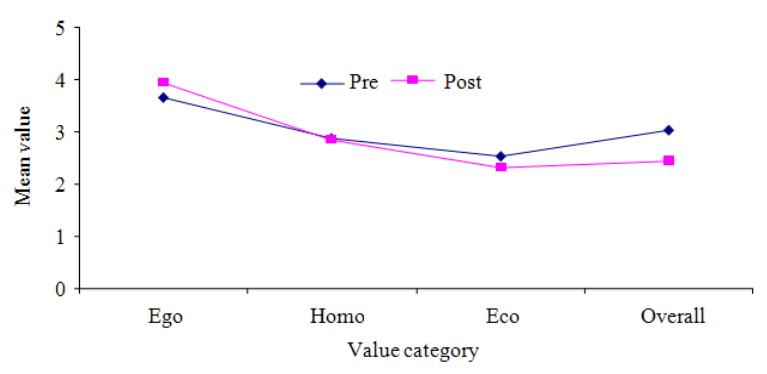

Fig. 1: Environmental profile

\begin{tabular}{|c|c|c|c|c|c|}
\hline \multirow[b]{2}{*}{ Item } & \multicolumn{2}{|c|}{ NEP mean } & \multirow[b]{2}{*}{ SD } & \multirow[b]{2}{*}{$\mathrm{t}$-value } & \multirow[b]{2}{*}{ sig } \\
\hline & Pre test & Post test & & & \\
\hline $1 \mathrm{We}$ are approaching the limit of the number of people the earth can support & 1.93 & 3.88 & 1.18 & 0.347 & 0.013 \\
\hline 2 The balance of nature is very delicate and easily upset. & 1.22 & 3.67 & 0.97 & 0.765 & 0.023 \\
\hline 3Humans have the right to modify the natural environment to suit their needs & 3.97 & 1.56 & 1.29 & -2.331 & 0.034 \\
\hline 4Humans were meant to rule over the rest of nature & 3.94 & 1.34 & 1.38 & -3.542 & 0.012 \\
\hline 5 When humans interfere with nature it often produces disastrous consequences & 1.56 & 3.76 & 1.03 & 0.333 & 0.000 \\
\hline 6Plants and animals exist primarily to be used by humans & 3.53 & 1.05 & 1.01 & -0.567 & 0.035 \\
\hline $\begin{array}{l}\text { 7To maintain a healthy economy we will have to develop a "steady state" economy where } \\
\text { industrial growth is controlled }\end{array}$ & 2.35 & 3.97 & 1.14 & 0.234 & 0.042 \\
\hline 8Humans must live in harmony with nature in order to survive & 2.11 & 3.55 & 0.98 & 0.451 & 0.003 \\
\hline 9The earth is like a spaceship with very limited room and resources & 2.12 & 2.99 & 1.24 & 0.655 & 0.043 \\
\hline $\begin{array}{l}\text { 10Humans need not adapt to the natural environment because they can remake } \\
\text { it to suit their needs }\end{array}$ & 3.56 & 1.32 & 1.25 & -0.879 & 0.032 \\
\hline 11There are limits to growth beyond which our industrialized society cannot expand & 1.45 & 2.75 & 0.96 & 1.451 & 0.002 \\
\hline 12Humans are severely abusing the environment & 1.22 & 3.97 & 0.99 & 0.237 & 0.034 \\
\hline
\end{tabular}


In other words prior to the treatment the preservice teachers disagreed with the statement. Upon completing the green chemistry experiments these preservice teachers tended to agree with the statement. For instance, for item 1 before the treatment the pre-service had the perception that increases in world population is not a problem as the earth possesses the capacity to support unlimited number of people. However, after the treatment they came to realization that earth can only support limited number of people (i.e., carrying capacity). For items 3, 4, 6 and 10, decrease in the mean values were noticed between pre test and post test. These 4 items are worded in disagreement with NEP. Prior to the treatment students supported the statements. However, after the treatment students expressed disagreement with the statements.

\section{DISCUSSION}

In general, the results of this study have demonstrated that green chemistry experiments could improve students' self-determined motivations. Selfdetermined motivation elevates an individual to perform behavior that the individual freely chooses to carry out (Black and Deci, 2000; Ryan and Deci, 2000; Mallett et al., 2007; Deci et al., 1991). These behaviors are performed for reasons originating from within the individual and maintained without the need of external incentives or in the presence of barriers to action. Oslbaldiston and Sheldon (2003) suggested that selfdetermined environmental behaviors can promote enduring behavioral changes because those behaviors are not controlled by the external sources of motivation. Furthermore, self-determined motivation is believed to advance positive behavioral consequences (Pelletier et al., 1998). According to Pelletier et al. (1998) self determined motivation is associated with greater interest, positive emotions, higher psychological well-being and stronger behavioral persistence. Pelletier et al. (1998) also asserted that in addition to constructs such as environmental satisfaction, environmental responsibility and self efficacy for environmental behaviors, self determined motivation was predicted as a more frequent enactment for environmental responsible behaviors. For instance, De Young (1989) demonstrated that self-determined motivations were significant determinants of recycling. The findings of this study have shown that green chemistry could be employed as a tool to enhance self-determined motivation.

The analysis of QEV indicates that after the treatment the students are less egocentric and more homocentric and ecocentric. In other word they are being more environmental. Egocentric values tend to revolve around concern for personal well-being. Individuals holding these values may be more concerned with pursuing an economically advantageous course of action in order to maximize personal success (Axelrod, 1994). They may also deny that humans have a negative effect on the environment (Stern, 2000). On the other hand, biocentric values revolve around the concern for the whole ecosystem or biosphere. Individuals who hold these values believe that the environment should be protected due to its intrinsic worth and the environment has value independent of its usefulness to humans. They place a high value on the earth and judge actions according to their effects on the biosphere (Kempton et al., 1995). Individuals holding these values will be the most likely to pursue a course of action which protects the environment, even if it involves personal sacrifice (Axelrod, 1994). The finding of this study is similar to Carson (1962) when he concluded that the majority possesses values which are centered on human beings rather than the biosphere.

The results showed that the integration of green chemistry is able to induce value change among our pre-service students. It is important that these future teachers embraced the proper values since as teachers they will have the tendency to express the values they find important to their students through pedagogical content knowledge (Veugelers, 2000). As Heaton et al. (2006) suggested embedding green chemistry principles could lead to development of curriculum and pedagogy that would lead to the development of values, knowledge and skills towards contributing to sustainable development.

The outcomes of the pre-test on students' proenvironmental attitudes are consistent with the results from a study conducted by Said et al. (2007) involving Malaysian secondary school students. The study by Said et al. (2007) to gauge their level of environmental understanding, awareness and knowledge indicates that current practice of environmental education has effectively raised environmental consciousness but was rather ineffective in changing action and behavior patterns. Students were not very enthusiastic in solving environmental problems (Karpudewan et al., 2006) and exhibit considerable apathy to engage proactively in environmental behaviors (Sharifah and Hashimah, 2006).

Although the Malaysian in-service teachers possess considerable level of environmental knowledge, they lack a general understanding of the underlying causes of the environmental problems (Said et al., 2003). Furthermore, the practices of environmental behavior amongst the teachers are not in concert with the level of 
environmental concern and knowledge. This circumstance prevail despite the notion that EE is being infused into conventional school subjects and environmental education has also have been included in the teacher education program (Curriculum Development Center, 2006).

\section{CONCLUSION}

In order to offset the environmental degradation of the 21 st century human behaviors need to be changed. The findings from the study showed that there is a significant difference between the pre-test and post-test mean values for intrinsic motivation (acts out of personal choice and interest), integrated regulation (behavior has been assimilated and grows into an integral part of self-concept), identified regulation (performs the activity by personal choice in order to attain goals) and interjected regulation (beginning to internalize the control of behavior). However, no significant differences were obtained for external regulation and amotivation (incapable of foreseeing the consequences of behavior). Behaviors performed for self-determined motives are behaviors that the individual freely chooses to carry out, performed for reasons originating from within the individual and maintained without the need of external incentives or in the presence of barriers to action. Self-determined environmental behaviors can promote enduring behavioral changes because those behaviors are not controlled by external sources of motivation.

The results of this study suggest that one way of improving self-determined motivation and promote attitude change is through the implementation of green chemistry. The nature of green chemistry is inherently suitable for promoting self-determined motivation and pro-environmental attitude. The implementation of green chemistry allowed for the integration of environmental issues in the teaching and learning of chemistry. Hence, students were able to systematically examine the nature of their own environmental attitudeeither in terms of their internal consistency, or consistency between what they believe and the practice of their everyday lives.

Integration of green chemistry permits the course to be interdisciplinary and teaches higher order cognitive skills learning. Through the green chemistry experiments, students develop a systematic approach to analyzing questions of environmental attitude; and to provide them with a framework for thinking critically about their own personal environmental attitude. It presents a paradigm shift in chemical education from algorithmic imparting knowledge type learning to higher order cognitive skill learning. It is hoped that with the knowledge gained through the course the preservice teachers could further disseminate and educate our children in schools. Early exposure to the challenges facing the natural world is the best way to engender interest in and respect for the ecology of our planet.

\section{REFERENCES}

Anastas, P.T. and J.C. Warner, 1998. Green Chemistry: Theory and Practice. 1st Edn., Oxford University Press, USA., ISBN: 978-19-850698-0, pp: 152.

Axelrod, J.L., 1994. Balancing personal needs with environmental preservation: Identifying the values that guide decisions in ecological dilemmas. J. Soc., 50: 85-104. DOI: 10.1111/j.15404560.1994.tb02421.x

Black, A. and E. Deci, 2000. The effects of instructors' autonomy support and students' autonomous motivation on learning organic chemistry: A selfdetermination theory perspective. Sci. Educ., 84: 740-756. DOI: 10.1002/1098-237X(200011).

Carson, R., 1962. Silent Spring. Ist Edn., Houghton Mifflin, ISBN: 0-618-24906-0, pp: 365.

Curriculum Development Center, 2009. Integrated Curriculum for Secondary Schools. http://www.moe.my/bpk

De Young, R., 1989. Exploring the difference between recyclers and non-recyclers: The role of information. J. Environ. Syst., 18: 341-351.

Deci, E.L. and R.M. Ryan, 1991. A Motivational Approach to the Self: Integration in Personality. In: Nebraska Symposium on Motivation, Perspectives on Motivation, Dienstbier, R. (Ed.). University of Nebraska Press, NE., ISBN: 0803216939, pp: 369.

Dunlap, R. and K.D. Van Liere, 2008. The new environmental paradigm. J. Environ. Educ., 40: 19-28. DOI: 10.3200/JOEE.40.1

Fien, J. and D. Tilbury, 1996. Learning for a Sustainable Environment: An Agenda for Teacher Education in Asia and the Pacific, UNESCOACEID, Bangkok, pp: 58-59. http://unesdoc.unesco.org/images/0010/001056/10 5607e.pdf

Haack, J., J.E. Hutchison, M.M. Kirchhoff and I.J. Levy, 2005. Going green: Lecture assignments and lab experiences for the college curriculum. J. Chem. Educ., 82: 974-978. DOI: 10.1021/ed082p974 
Heaton, A., S. Hudgson, T. Overton and R. Powell, 2006. The challenge to develop chlorofluorocarbon (CFC) replacements: A problem based learning case study in green chemistry. Chem. Educ. Res. Practice, 7: 280-287. ISSN: 1109-4028

Kempton, W., J.S. Boster and J.A. Hartley, 1995. Environmental Values in American Culture. 1st Edn., MIT Press, ISBN: 0-262-11191-8, pp: 320.

Karpudewan, M., Z. Ismail and N. Mohamed, 2006. Greening the high school chemistry curriculum to address education for sustainable development. Proceeding of the International Science Education Conference, Nov. 22-24, National Institute of Education, Singapore, pp: 1007. ISSN: 981-056714-6

Karpudewan, M., Z. Ismail and N. Mohamed, 2006. Knowledge, beliefs, desires and behavior of chemistry pre-service teachers towards the environment. Proceeding of the 2006 International Organization of Science and Technology Education, July 30-Aug. 4, Penang, Malaysia, 2006, University Sains Malaysia, ISBN: 983-270039-6, pp: 809.

Markku, K. and W. Riitta, 2000. An Environmental education program for teacher trainers in Finland. J. Environ. Educ., 31: 31-37. DOI: 10.1080/00958960009598637

Mallett, C., M. Kawabata, P. Newcombe, A.D. Forera and S. Jackson, 2007. The revised six-factor Sport motivation scale. Psychol. Sport Exer., 8: 615-621. DOI: $10.1016 /$ j.psychsport.2006.12.005

May, T.S., 2000. Elements of success in environmental education through practitioner eyes. J. Environ. Educ., 31: 4-11. DOI: $10.1080 / 00958960009598639$

McMillan, E.E., T. Wright and K. Beazley, 2004. Impact of a university-level environmental studies class on students' values. J. Environ. Educ., 35: 19-28.

McKeown-Ice, R., 2000. Environmental education in the United States: A survey of preservice teacher education programs. J. Environ. Educ., 32: 4-11. DOI: $10.1080 / 00958960009598666$

National Policy on Environment, 2002. Department of Environment, Ministry of Natural Resources and Environment. http://www.doe.gov.my

Orr, D., 1991. What is education for? 25 January 2009; http://www.content.org/ICLIB/IC27?Orr.htm

Oslbaldiston, R. and K.M. Sheldon, 2003. Promoting internalized motivation for environmentally responsible behavior: A prospective study of environmental goals. J. Environ. Psychol., 23: 349357. DOI: $10.1016 / \mathrm{S} 0272-4944(03) 00035-5$
Pelletier, L.G., M.K. Tuson, G.I. Demers, K. Noels and M.A. Beaton, 1998. Why are you doing things for the environment? The Motivation toward the Environment Scale (MTES)? J. Applied Soc. Psychol., 28: 437-468. DOI: 10.1111/j.15591816.1998.tb01714.x

Peter, V.P., B. and B.P. Jelle, 2007. Evaluating the implementation process of environmental education in pre-service teacher education: Two case studies. J. Environ. Educ., 38: 47-54. DOI: 10.3200/JOEE.38.1.47-54.

Powers, A.L., 2004. Teacher preparation for environmental education: Faculty perspectives on the infusion of environmental education into pre service methods courses. J. Environ. Educ., 35: 17-32.

Ryan, R.M. and E.L. Deci, 2000. Self-determination theory and the facilitation of intrinsic motivation, social development and well-being. Am. Psychol., 55: 68-78. PMID: 11392867

Said, A.M. F.-R. Ahmadun, L.H. Paim and J. Masud, 2003. Environmental concerns, knowledge and practices gap among Malaysian Teachers. Int. J. Sustain. Higher Educ., 4: 305-313. DOI: 10.1108/14676370310497534

Said, A.M., Y. Nurizan, A. Fakhru'l-Razi, 2007. Environmental comprehension and participation of Malaysian Secondary School Student. Environ. Educ. Res., 13: 17-31. DOI: 10.1080/13504620601122616

Seguin, C., L.G. Pelletier and J. Hunsley, 1999. Predicting environmental behaviors: The influence of self-determined motivation and information about perceived environmental health risks. J. Applied Soc. Psychol., 29: 1582-1604. DOI: 10.1111/j.1559-1816.1999.tb02043.x

Sharifah, N.S.I. and Y.N. Hashimah, 2006. Malaysian pre and in-service teacher prepareness in teaching for sustainability. Proceeding of the 2006 International Organization of Science and Technology Education, July 30-Aug. 4 Penang, Malaysia, University Sains Malaysia, ISBN: 9832700-39-6, pp: 809.

Stern, P., 2000. Psychology and the science of humanenvironment interactions. Am. Psychol., 55: 523-530. PMID: 10842433

Taskin, O., 2009. The environmental attitudes of Turkish senior high school students in the context of post materialism and the new environmental paradigm. Int. J. Sci. Educ., 31: 481-502. DOI: 10.1080/09500690701691689

Veugelers, W., 2000. Different ways of teaching values. Educ. $\quad$ Rev., 52: 37-46. DOI: $10.1080 / 00131910097397$ 
Villacorta, M., R. Koestner and N. Lekes, 2003. Further validation of the motivation toward the environment scale. Environ. Behav., 35: 486-505. DOI: 10.1177/0013916503035004003

Wardencki, W., J. Curylo and J. Namiesnik, 2005. Green chemistry-current and future issues. Polish J. Environ. Stud., 14: 389-395.
Yencken, D., J. Fien and H. Sykes, 2000. Environment, Education and Society in the Asia-Pacific: Local Traditions and Global Discourses. Routledge, ISBN: 0-415-20581-6, pp: 339. 